\title{
EFL Students' Coherence Skill in Writing: A Case Study of Third Year Students of Bachelors in English Language
}

\author{
Enas Abdelwahab Eltom RahmtAllah ${ }^{1}$ \\ ${ }^{1}$ English Department, College of Sciences and Arts, Unaizah, Qassim University, Saudi Arabia \\ Correspondence: Enas Abdelwahab Eltom RahmtAllah, English Department, College of Sciences and Arts, \\ Unaizah, Qassim University, Unaizah 51911, Saudi Arabia.
}

Received: June 20, 2020

Accepted: July 1, 2020

Online Published: July 14, 2020

doi: $10.5539 /$ elt.v13n8p120

URL: https://doi.org/10.5539/elt.v13n8p120

\begin{abstract}
Writing is considered an essential learning tool for all content areas. However, to master and have excellent writing skills for EFL students of undergraduate programs is challenging. Cohesion and coherence are both crucial textual elements to master writing. The present study examined coherence in English essays written by 46 female Saudi EFL third year at Unaizah College of Sciences and Arts, Qassim University. Examination of essays by the subject group designed to answer the research question. 1.) To what extent are EFL students competent in achieving coherence in writing skills? Each student was asked to write two essays (a writing test that included two essay questions). The data were analyzed through SPSS. The study results demonstrated that learners are not competent in achieving coherence in their writing tasks. In light of these results, recommendations are presented. The results also recommend further studies to investigate coherence and action research to improve this crucial skill among undergraduate Saudi EFL learners.
\end{abstract}

Keywords: coherence, cohesion, skill, writing

\section{Introduction}

Writing is the most important of the many skills students need for the University. Writing skill is not just the words written on the paper; it is the effective communication of complex ideas in the purest form of words. Initially, the writing was seen as a product, an approach that pays individual attention to handling linguistic skills effectively, such as grammar and vocabulary. For this reason, its procedures are widely connected to conventional methodologies of language teaching whose primary purpose is accuracy and writing at word or sentence level (Kroll, 2001; Larsen-Freeman \& Anderson, 2011). Recent writing is seen as a complex task, a social act that represents the communication skills of the writer, which are difficult to acquire and learn, especially in an EFL context (Shokrpour and Fallahzadeh, 2007). Without the ability to write, it is difficult to survive in a competitive learning environment where the university student will continue to commit errors such as blatant syntax errors, spelling and grammatical errors. (Lester, 2017). Fageeh (2003) mentions that writing is a dynamic process that needs tremendous effort in learning and teaching because it must be learned through conscious exposure. Marzaban \& Sarjami (2014) remark that many EFL students think that writing is one of the most challenging skills they are expected to master. The challenge, according to Richards and Renandya (2002), arises from the development and organization of ideas and their translation into readable text. Ahmed (2010) notes that when they learn to write, not only do students have problems, but teachers also face difficulties when they teach to write. He adds that both teachers and students noticed that it seems more complicated and exhausting to learn writing skills than to learn the other language skills. At the university level, students need to learn how to produce academic texts so that ideas can be expressed to other L2 users. Textual coherence and cohesion are, therefore, essential ingredients of academic writing (Hyland, 2006). Cohesion and coherence are both crucial textual elements to master writing (Liu and Braine, 2005). Coherence means the association of ideas at the level of the idea, and Cohesion implies, at the sentence level, the relation of ideas. Coherence refers to the "rhetorical" aspects of writing, which include the development and support of argument (e.g. development of thesis statements), the synthesis and integration of readings, organization, and clarification of ideas. The cohesion of writing focuses on the "grammatical" elements of learning (Min, 2010). According to Hyland (2006), Coherence is how a text makes sense to readers because of the importance and usability of its meaning, idea and theory configuration. Therefore, to promote comprehension of the reader, Hinkel (2004) mentions that all the 
sentences that make up each paragraph must be organized logically by following a continuous order based on the meaning they are trying to convey. Coherence is essential in writing within this framework since it involves expressing consistent and understandable ideas in a text. Castro (2004) defines coherence as the link in a text that links ideas and makes the readers' thoughts flow meaningfully and clearly. As a teacher and researcher, Lee (2002) believed that the concept of coherence was not definite so that teachers in writing had difficulty teaching and evaluating students. Therefore, most EFL learners have writing problems, notably in producing a coherent and cohesive text. Coherent and cohesive instruments are frequently misused or overused by learners seeking to rectify their development of learning. Most of them seem to have a vague understanding of coherent and cohesive devices and are not well rounded up with strategies that can help them improve their writing (Aguieb and Bouaziz, 2017). Therefore, the present study aims to investigate Saudi EFL students' coherence skill in writing. Specifically, the study aims at providing data-supported answers to the following research question:

- To what extent are Saudi EFL students competent in achieving coherence in writing skill when they use

a) repetition to link ideas, sentences, and paragraphs.

b) transitional expressions to link Ideas, sentences, and paragraphs.

c) pronouns to link sentences.

d) synonyms to link ideas and create a variety.

e) parallel structures to link ideas, sentences, and paragraphs.

\section{Literature Review}

Although cohesion and coherence both refer to the meaning of relationships connectivity that may or may not be linguistically encoded are descriptive categories that vary in nature. Bublitz (2011) mentions that coherence is a concept that, in its complexity, is not yet fully understood and is an issue of continuing debate. While it has undeniably found its place in the study of text and discussion as a critical word, its usage remains variable to the degree that it goes far beyond the reach of a handbook article to offer a detailed overview of even the main view. Aguieb and Bouaziz, (2017) point out that coherence is a debatable subject up till now because it was defined differently by different linguists and researchers and approached from varied angles. According to Sherman, Slawson, Whitton, and Wiemelt (2010), coherence is a component of writing skill that proves to be an essential part of and a virtual guarantee of the quality of writing. It is accomplished by seamlessly combining sentences and concepts and flowing together. An essay without coherence can inhibit the ability of a reader to comprehend the essay's ideas and main points. Coherence allows the reader to move from one idea to another, from one sentence to the next, and from one paragraph to the next, efficiently throughout the essay. There are varieties of ways to achieve coherence in writing. Oshima \& Hogue (2006) propose four of these:

1. Key nouns repeat

2. Uses consistent pronunciations

3. Making use of transition signals to connect ideas

4. Arranging your ideas according to logic

Sherman et al. (2010) mention five ways to achieve coherence in writing:

1. Use repeats to link ideas, phrases, and paragraphs.

2. Use transitional terms to connect concepts, phrases, and paragraphs.

3. Use pronouns to link sentences.

4. Using synonyms for connecting ideas and building diversity.

5. Use parallel structures to link together ideas, phrases and paragraphs

Lee (2002) identifies five features of a coherent text as follows:

1. The text has a macrostructure that provides a sense suited to the purposes and functions of its communication. The macrostructure is an outline of the text's main categories or features.

2. The text has a structure that guides the understanding of information organization and subject development, which means giving old information before new information.

3. The text shows the connectivity of the underlying content, as demonstrated by the relationships between offers. If the ideas it contains are explained or exemplified in clarity, a text is coherent.

4. The text has cohesive devices to create a connection between sentences and paragraphs. 
5. The text contains appropriate metadiscourse features. Text markers in metadiscourse help readers organize, interpret, and evaluate knowledge.

Lee recommended when teaching students coherence in writing classes that teachers should introduce and discuss the topic of coherence. Then, the students should be led to read a text, discuss, and determine if it is coherent. After that, the teachers offer students the criteria for coherence. Awareness of coherence among the learners is raised through mini-text analyzes in which the teacher serves as facilitator. In the end, students are asked to write independently.

Briesmaster and Etchegaray (2017) tried to identify the impact of metacognitive training on the production of coherence and cohesion in EFL learner writing at the paragraph level. The findings indicate that the EFL students had used more metacognitive techniques while writing after receiving the intervention. In the field of cohesion a small change has also been noted. To this end, the EFL classroom will expand the incentives for writing and reflecting practices while developing in the L2 through a wider intervention.

Ahmed (2010) conducted a study that aims at investigating students' cohesion and coherence problems in Egyptian EFL essay writing. The study findings revealed that English student teachers in Egypt are experiencing some issues of coherence and cohesion in their writing in English. Some issues have been identified concerning coherence problems in their English writing, such as difficulty writing the introduction, the thesis statement, the subject paragraph, essay concluding sentences, and writing the conclusion.

Fareh (2014) attempts to identify the errors that Arab EFL learners commit in writing English essays at the macrolinguistic level. She notes that Arab learners of English encounter major macrolinguistic problems in writing English essays. Among these problems are coherence and cohesion problems.

Aguieb and Bouaziz (2017) investigate students' problems in using coherent and cohesive devices from a discourse analysis perspective. The corpus of their study consists of 23 argumentative essays that were analyzed on the basis of Halliday and Hassan (1976) cohesion framework. The data obtained show that the students used all the types of grammatical and lexical cohesive devices along with their subtypes. The outcomes of the analysis also showed the problems that the students encountered; they were mostly misused, overuse, and ambiguity. Aguieb and Bouaziz (2017) note that most EFL learners have difficulties in producing a coherent and cohesive text. Coherent and cohesive tools are frequently misused or overused by learners seeking to rectify the development of learning. Most EFL learners seem to have a vague conception of coherent and consistent devices and are not well-rounded with the techniques that help them develop their writing output. EFL learners continue to concentrate on the verb-subject agreement at the sentence level and struggle to create a coherent and meaningful piece of writing that renders them incapable of communicating effectively by writing.

Ariyanti and Fitriana (2017) have observed the writing class and the essays of the EFL students are of poor quality. This situation portrays the fact that writing is a complex learning skill in acquiring the English language. For this reason, they investigate the difficulties faced by EFL students in the writing of essays as well as the learning needs of the students to have a better quality of English composition. The findings showed significant difficulties for students in terms of grammar, cohesion, and coherence.

Ahmed (2010) notes that some research papers in the Arab world have highlighted the issues of coherence between students in English writing. Written texts by Arab students, for example, revealed that repetition, parallelism, sentence length, lack of variation, and misuse of specific cohesive devices are significant sources of incoherence and textual deviation. Such challenging issues motivated the researcher to focus her current study on investigating Saudi Arabia university students' use of coherence in writing.

\section{Method}

The study is descriptive. The methodology of this study is a combination of quantitative and qualitative analysis.

\subsection{Participants}

The participants in the study are, 46 students, the third level female students, the Department of English, Unaizah College of Sciences and Arts, Qassim University. The student participants are required to take an intensive course before joining the English department. The students had English skills, which ranged from below average to average. They have been taught to write a coherent and cohesive essay, as well as the appropriate use of coherent methods.

\subsection{Instrument}

The research question belongs to a descriptive study. This study was carried using a diagnostic test. The participants were asked to write two essays. The diagnostic test was based on the following principles: 
- In order not to feel restricted, they were given a choice to choose two out of three topics.

- The participants were given some instructions so they can understand the task and not get lost.

They were given two hours and a half to write, and they did not know about the subject of the study.

\subsection{Coherence Analysis of Essays}

This study examined the frequency of the use of repetition, transitional expressions, pronouns, synonyms, and parallel structures in EFL learners writing tasks to achieve coherence. The data were analyzed through the Statistical Package for the Social Sciences (SPSS), and a series of statistical analyses (frequencies, Mean, and Standard Deviation) were employed in this study, too.

\section{Results and Discussion}

To answer the study question, the descriptive statistics (Mean and Standard Deviation) of the use of each method (repetition, transitional expressions, pronouns, synonyms, and parallel structures) were computed separately. It's worthwhile to mention that in this study if the mean value for the results in each method is less than 15 , this means that students are not competent in that skill.

a) The findings in the Table 1. show the results regarding the use of repetition to link ideas, sentences, and paragraphs in the test:

Table 1. Mean Frequency of the use of repetition

\begin{tabular}{cccccc}
\hline Ss N. & Mean & Median & $\begin{array}{c}\text { Std. } \\
\text { Deviation }\end{array}$ & Minimum & Maximum \\
\hline 46 & 10.24 & 10.00 & 3.219 & 4 & 18 \\
\hline
\end{tabular}

Note. $\mathrm{Ss}=$ Students number

Table 1. reveals that the Mean score of this method in the test is 10.24 and the Std. Deviation is 3.21. The Mean is less than 15, which means that the students are not competent in the use of this method to achieve coherence.

b) The Findings in Table 2. demonstrate the results regarding the use of transitional expressions to link ideas, sentences, and paragraphs in the test:

Table 2. Mean Frequency of the use of transitional expressions

\begin{tabular}{cccccc}
\hline Ss N. & Mean & Median & $\begin{array}{c}\text { Std. } \\
\text { Deviation }\end{array}$ & Minimum & Maximum \\
\hline 46 & 9.07 & 8.00 & 3.861 & 2 & 19 \\
\hline
\end{tabular}

The results in Table 2. illustrate that the Mean score of this method in the test is 9.07 and the Std. Deviation is 3.8. The Mean is less than 15, which means that the students are not competent in the use of this method to achieve coherence.

c) The findings in Table 3. show the results regarding the use of pronouns to link sentences in the test:

Table 3. Mean Frequency of the use of pronouns

\begin{tabular}{cccccc}
\hline Ss N. & Mean & Median & $\begin{array}{c}\text { Std. } \\
\text { Deviation }\end{array}$ & Minimum & Maximum \\
\hline 46 & 12.83 & 11.00 & 5.208 & 6 & 30 \\
\hline
\end{tabular}

The results in Table 3. display that the Mean score of this skill in the test is 12.83 and the Std. Deviation is 5.20. The Mean is less than 15, which means that the students are not competent in this skill.

d) The findings in Table 4. present the results regarding the use of synonyms to link ideas and create variety in the test:

Table 4. Mean Frequency of the use of synonyms

\begin{tabular}{cccccc}
\hline Ss N. & Mean & Median & $\begin{array}{c}\text { Std. } \\
\text { Deviation }\end{array}$ & Minimum & Maximum \\
\hline 46 & 3.67 & 4.00 & 1.620 & 0 & 8
\end{tabular}

The students are not competent in this skill as table 4. reveals that the Mean score of this skill in the test is 3.67 and the Std. Deviation is 1.6. 
e) The findings in Table 5. present the results regarding the use of parallel structures to link ideas, sentences, and paragraphs in the test:

Table 5. Mean Frequency of the use of parallel structures

\begin{tabular}{cccccc}
\hline Ss N. & Mean & Median & $\begin{array}{c}\text { Std. } \\
\text { Deviation }\end{array}$ & Minimum & Maximum \\
\hline 46 & 4.09 & 4.00 & 1.620 & 1 & 7 \\
\hline
\end{tabular}

The results in Table 5. display that the Mean score of this skill in the test is only 4.09 and the Std. Deviation is 1.620. The Mean is less than 15, which means that the students are not competent in this skill, too.

Chart 1. shows the percentage of the methods used to achieve coherence that occurred in 92 essays. The total number (the frequency) of the coherent ways used in the test is only 1963. The learners employed all the five methods related to this study to achieve coherence, despite the significant difference among them. The learners depend mostly on the use of pronouns to link ideas, as it represents $30 \%$ of the total consumption of coherent devices. After that, the use of repetition and transitional expressions appeared in the second place where each of them represents $24 \%$. Then, the use of parallel structures to link ideas, sentences and paragraphs comes in third place with $12 \%$, while synonyms come in fourth place with only $10 \%$.

1. Use of repetition

2. Use of transitional expresstion

3. Use of pronouns

4. Use of synonyms

5. Use of parallel structures

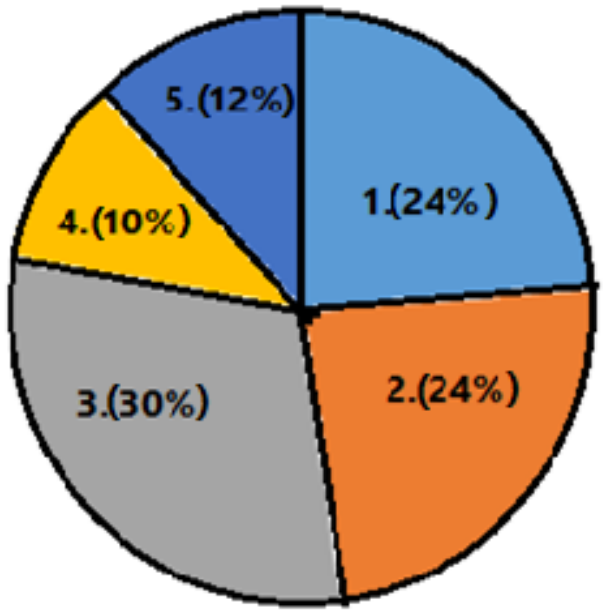

Chart 1. the percentage of the methods used to achieve coherence

The purpose of this study was an attempt to explore whether EFL students are competent in coherence in writing skills. The methods to achieve coherence in writing that has been chosen in this study were five (repetition, transitional expressions, pronouns, synonyms, and parallel structures). The results show that students are not competent in the use of these methods. These results agree with the findings of Ahmed (2010), Aguieb, and Bouaziz (2017) that students are generally weak in achieving coherence in their writing tasks. Many students get confused when they get low marks in writing. They think that it is enough to take care of the correct structure and spelling only. Although the participants in this study were directed to use the five methods to achieve coherence, they focused on accuracy and writing at the word or sentence level. Clearly, they are affected by the traditional writing approach that pays individual attention to the successful management of linguistic knowledge, such as grammar and vocabulary (Kroll, 2001; Larsen-Freeman \& Anderson, 2011).

\section{Conclusions of the Study}

Due to the argument over the students' weakness in achieving coherence in their writing tasks, the present study attempted to investigate EFL students' coherence skills in writing.

To realize this aim, a descriptive study was carried out in the Department of English, College of Sciences and Arts in Unizah, Qassim University.

The number of subjects involved in the study was 46 undergraduate EFL female learners. The participants were given two hours and a half and asked to write two essays.

After collecting the data, it was found that the students employed all the five methods related to this study to achieve coherence, but the students' achievement was generally low. The results indicated that the students are 
not competent in using the five methods (repetition, transitional expressions, pronouns, synonyms, and parallel structures) to achieve coherence in their writing tasks.

The results thus suggest that for improving writing and producing successful writer, EFL learners should practice writing coherent tasks instead of focusing on correct spelling and grammar only. Besides, incorporating reading into writing is necessary in order to improve students' sense of coherence.

\section{Recommendations}

A number of recommendations are made based on the above findings.

1) Students should be exposed to different topics; this will give them opportunities to practice different cohesive and coherent ties to build cohesion and coherence.

2) Teachers should teach students coherence by ideas and organizational focus and train students ' minds and thought processes by regular writing practices.

3) There is a need for further researches (action research) to be done to investigate cohesion and coherence to improve these crucial skills among undergraduate EFL learners.

\section{References}

Aguieb, F., \& Bouaziz, S. (2017). Investigating EFL students' problems in using coherent and cohesive devices in academic writing from a discourse analysis perspective.

Ahmed, A. H. (2010). Students' problems with cohesion and coherence in EFL essay writing in Egypt: Different perspectives. Literacy Information and Computer Education Journal (LICEJ), 1(4), 211-221. https://doi.org/10.20533/licej.2040.2589.2010.0030

Ariyanti, A., \& Fitriana, R. (2017, October). EFL Students' Difficulties and Needs in Essay Writing. In International Conference on Teacher Training and Education 2017 (ICTTE 2017). Atlantis Press. https://doi.org/10.2991/ictte-17.2017.4

Ashraf, T. A. (2018). Teaching English as a Foreign Language in Saudi Arabia: Struggles and Strategies. International Journal of English Language Education, (6)1, 133-154. https://doi.org/10.5296/ijele.v6i1.13148

Briesmaster, M., \& Etchegaray, P. (2017). Coherence and cohesion in EFL students' writing production: The impact of a metacognition-based intervention. Íkala, revista de lenguaje y cultura, 22(2), 183-202. https://doi.org/10.17533/udea.ikala.v22n02a02

Bublitz, W. (2011). Cohesion and coherence. Discursive Pragmatics, John Benjamins Publishing Company, Amsterdam/Philadelphia, 37-49. https://doi.org/10.1075/hoph.8.03bub

Castro, C. D. (2004). Cohesion and the social construction of meaning in the essays of Filipino college students writing in L2 English. Asia Pacific Education Review, 5(2), 215-225. https://doi.org/10.1007/BF03024959

Dueraman, B. (2006). Cohesion and coherence in English essays written by Malaysian and Thai medical students (Doctoral dissertation, Prince of Songkla University).

Fageeh, A. (2003). Saudi college students beliefs regarding their English writing difficulties (Unpublished doctoral dissertation). Indiana University of Pennsylvania, PA.

Fareh, S. (2014). Macrolinguistic errors in Arab EFL learners' essays. Procedia-Social and Behavioral Sciences, 141, 923-933. https://doi.org/10.1016/j.sbspro.2014.05.161

Ghasemi, M. (2013). An investigation into the use of cohesive devices in second language writings. Theory and Practice in Language Studies, 3(9), 1615. https://doi.org/10.4304/tpls.3.9.1615-1623

Harmer, J. (2007). How to teach English (new ed.). England: Pearson Education Limited. https://doi.org/10.1093/elt/ccn029

Hedge, T. (2005). Writing. Oxford: Oxford University Press.

Hinkel, E. (2004). Teaching Academic ESL Writing: Practical Techniques in Vocabulary and Grammar. New York, NY/London: Routledge. https://doi.org/10.4324/9781410609427

Hyland, K. (2006). English for Academic Purposes: An Advanced Resource Book. Abingdon: Routledge.

Kroll, B. (2001). Considerations for teaching an EFL/ESL writing course. In M. Celce-Murcia (Ed.), Teaching English as a Second or Foreign Language (3rd ed.). (pp. 219-232). Boston, MA: Heinle \& Heinle. 
Kusumawardani, M. A. (2018). Student's strategies in building coherence in writing English essay (Doctoral dissertation, UIN Sunan Ampel Surabaya).

Larsen-Freeman, D., \& Anderson, M. (2011). Techniques and Principles in Language Teaching (3rd ed.). Oxford: Oxford University Press.

Lee, I. (2002). Helping Students Develop. Coherence. In Forum. US Department of State.

Lester, L., (2017). Why Is Writing Skill The Most Important Skill You Need In University Life? Retrieved on 20/5/2020

from https://www.munplanet.com/articles/academical-writing-skills/why-is-writing-skill-the-most-important-skil 1-you-need-in-university-life

Liu, M., \& Brain, G. (2005). Cohesive features in argumentative writing produced by Chines undergraduates. System, 33(4), 623-636. https://doi.org/10.1016/j.system.2005.02.002

Marzban, A., \& Sarjami, S. M. (2014). Collaborative negotiated feedback versus teacher-written feedback: Impact on Iranian intermediate EFL learners' writing. Theory and Practice in Language Studies, 4(2), 293-302. https://doi.org/10.4304/tpls.4.2.293-302

Medve, V. B., \& Takač, V. P. (2013). The influence of cohesion and coherence on text quality: A cross-linguistic study of foreign language learners' written production. In Language in cognition and affect (pp. 111-131). Springer, Berlin, Heidelberg. https://doi.org/10.1007/978-3-642-35305-5_7

Min, Y. K. (2010). Culture, Cognition, and context: situated literacy practices of L1 and L2 Writing Programs (Doctoral dissertation, University of Illinois at Urbana-Champaign).

Oshima, A., \& Hogue, A. (2007). Introduction to Academic Writing (3rd ed.). White Plains, NY: Pearson Education.

Oshima, A., \& Hogue, A. (2006). Writing academic English. Addison Wesley Longman.

Richards, J. C., \& Renandya, W. A. (2002). Methodology in language teaching: An anthology of current practice. Cambridge: Cambridge University Press. https://doi.org/10.1017/CBO9780511667190

Sherman, D., Slawson, J., Whitton, N., \& Wiemelt, J. (2010). The little brown handbook. Longman (pp, 42-45).

Shokrpour, N., \& Fallahzadeh, M. (2007). A Survey of the Students and Interns' EFL Writing Problems in Shiraz University of Medical Sciences. Asian EFL Journal, 9(1).

Shukri, N. A. (2014). Second Language Writing and Culture: Issues and Challenges from the Saudi Learners' Perspective. Arab World English Journal, 5(3).

Starkey, L. (2004). How to write Great Essays. 1st Ed. New York: Learning Express.

\section{Copyrights}

Copyright for this article is retained by the author(s), with first publication rights granted to the journal.

This is an open-access article distributed under the terms and conditions of the Creative Commons Attribution license (http://creativecommons.org/licenses/by/4.0/). 